\title{
Macroglobulinemia with Bence Jones Proteinuria: Comparison of Urinary Protein and L Chain of Serum Proteins *
}

\author{
Dale Gross and Wallace V. Epstein \\ (From the Department of Medicine, Rheumatic Disease Group, University of California \\ School of Medicine, San Francisco, Calif.)
}

Edelman and Gally (1) have recently shown that an individual's Bence Jones proteins are chemically and physically similar to the low molecular weight polypeptides ( $\mathrm{L}$ chains) obtained by reductive cleavage of his myeloma proteins. Indeed, Putnam (2) has shown that peptide maps of the tryptic digests of oxidized Bence Jones proteins correspond to a portion of the peptide map of similarly treated autologous serum myeloma protein.

Edelman and Benacerraf (3) have postulated that the manufacture of the $\mathrm{L}$ polypeptide chains is asynchronous in multiple myeloma, and thus a part of the cell output appears in the urine as Bence Jones protein, whereas other chains are incorporated into the circulating myeloma globulin. It was of interest, therefore, to examine the uncommon instance of Bence Jones proteinuria in a patient with Waldenström's macroglobulinemia and particularly to compare the $\mathrm{L}$ chains of the serum macroglobulins and $\gamma_{2}$-globulins with the urinary Bence Jones protein.

Evidence is presented to show that the Bence Jones protein is chemically and antigenically similar to the $L$ chain derived from the patient's macroglobulin and antigenically deficient when compared to the $\mathrm{L}$ chain of the autologous $7 \mathrm{~S} \gamma_{2}$-globulin.

\section{Materials and Methods}

Clinical information. The patient in the present study, a 74-year-old Caucasian male, was admitted to the Ear, Nose, and Throat Service of the University of California

* Submitted for publication July 16, 1963 ; accepted September 19, 1963.

Supported in part by grants A-1229 and B-1099 from the National Institutes of Health, Bethesda, Md., a grant from The National Foundation, and funds from the Research Committee of the University of California School of Medicine.
Medical Center, in January 1963, because of gradual, progressive loss of hearing during the preceding year. He had always been in excellent health except for several episodes of unexplained epistaxis one year before admission. In the course of the initial physical examination, hepatomegaly was detected, and initial laboratory studies revealed a $3+$ proteinuria positive for Bence Jones protein and a normochromic, normocytic anemia with marked rouleaux formation. Additional laboratory studies showed a hemoglobin of $9.3 \mathrm{~g}$ per $100 \mathrm{ml}$, hematocrit of $29 \%$, and leukocyte count of 5,100 per $\mathrm{mm}^{3}$. The total serum protein was $11.4 \mathrm{~g}$ per $100 \mathrm{ml}$; serum electrophoretic analysis showed $20 \%$ albumin and $61 \% \gamma$-globulin. A Sia test showed a $4+$ reaction. Bone marrow aspiration detected lymphocytosis and plasmacytosis, and an X-ray bone survey demonstrated generalized demineralization.

Materials. The sodium salts of reagent grade phosphate and acetate were used for the preparation of the buffers; reagent grade urea was used. Additional materials were mercaptoethanol, ${ }^{1}$ iodoacetamide, ${ }^{2}$ carboxymethyl-cellulose (CM-cellulose, $0.8 \mathrm{mEq}$ per $\mathrm{g}$ ),,$^{3}$ and diethylaminoethyl-cellulose (DEAE-cellulose, $0.9 \mathrm{mEq}$ per $\mathrm{g}) .^{3}$ The exchangers were recycled through acid and base washes before use. Also used were cross-linked dextran (140 to 400 mesh) ${ }^{4}$ and a crystalline preparation of trypsin. ${ }^{5}$

Protein analysis. Protein concentrations were estimated by optical absorption at $280 \mathrm{~m} \mu$ in 1-cm cells or by the modified Folin-Ciocalteau method (4). One OD unit at $280 \mathrm{~m} \mu$ was assumed to be the equivalent of 1 $\mathrm{mg}$ of protein per $\mathrm{ml}$.

Ultracentrifugation. Proteins were analyzed in the Beckman Spinco Model E analytical ultracentrifuge using schlieren optics. Sedimentation coefficients were determined by the procedures described by Schachman (5). The sedimentation coefficients for the macroglobulins were derived by extrapolation of the experi-

\footnotetext{
${ }^{1}$ Eastman Organic Chemicals, Rochester, N. Y.

2 Mann Research Laboratories, New York, N. Y.

${ }^{3}$ CM-cellulose, Selectacel no. 76; DEAE-cellulose, Selectacel no. 70. Carl Schleicher and Schuell Co., Keene, N. H.

4 Sephadex G-100, Pharmacia, Uppsala, Sweden.

${ }^{5}$ Lot no. 6112, Worthington Biochemical Corp., Freehold, N. J.
} 
mentally obtained values at various concentrations to infinite dilution. The sedimentation coefficients of other protein samples were determined from data using single concentrations of the proteins. The partial specific volume was assumed to be $0.73 \mathrm{ml}$ per $\mathrm{g}$. All samples were dialyzed against $0.1 \mathrm{M} \mathrm{NaCl}$ and $0.01 \mathrm{M}$ phosphate at $\mathrm{pH} 7$ or $\mathrm{pH} 8$ before centrifugation.

Isolation of the macroglobulins and $7 S \gamma$-globulins. Ultracentrifugal analysis of the patient's serum had revealed $4.5 \mathrm{~g}$ of protein per $100 \mathrm{ml}$ having a sedimentation value of $17 \mathrm{~S}$ or higher. This serum was dialyzed against $0.15 \mathrm{M} \mathrm{NaCl}$, and the macroglobulin was isolated as a precipitated euglobulin by the addition of one part of the dialyzed serum to six parts of deionized water. This mixture was allowed to remain at $4^{\circ} \mathrm{C}$ for approximately 1 hour before centrifugation. The macroglobulin was further purified by four more euglobulin precipitations and then characterized by analytical ultracentrifugation.

The $\gamma_{2}$-globulin of the patient's serum was isolated from the supernatant fluid acquired during the first euglobulin precipitation. This fluid was equilibrated against $0.02 \mathrm{M}$ phosphate at $\mathrm{pH} 8$ and passed through a DEAEcellulose column $(4.0 \times 39 \mathrm{~cm})$ equilibrated with the same buffer (6). The first effluent containing diluted $7 \mathrm{~S}$ $\gamma$-globulin was further purified and concentrated on CM-cellulose. The final product was dialyzed against water and lyophilized.

The $\gamma_{2}$-globulin of a normal human serum was isolated by modification of the described chromatographic procedures (6).

Isolation and purification of the urine proteins. Random urine specimens from the patient showed $0.15 \mathrm{~g}$ of protein per $100 \mathrm{ml}$ of urine as measured by the biuret method. Twenty-four hour collections of urine were dialyzed against multiple changes of distilled water for 3 days, with sodium ethyl mercurithiosalicylate (Merthiolate) used as a preservative for the first 2 days. Some protein precipitated and could not be redissolved in salt solutions; this precipitated protein was not investigated further. The dialyzed preparations were stored frozen or as a dry powder after lyophilization.

The dialyzed urine was equilibrated against $0.01 \mathrm{M}$ acetate at $\mathrm{pH} 5$ and chromatographed on CM-cellulose, using salt and $\mathrm{pH}$ gradients as described under Results. A fraction obtained from this column and having characteristic properties of Bence Jones proteins was further purified on DEAE-cellulose.

Thermosolubility characteristics of the proteins were examined in an acetate buffer, $\mathrm{pH} 5.0$, ionic strength $(\mu)$ $=0.2(7)$. The turbidity of the protein solutions was observed visually in a water bath that was gradually heated to boiling.

Reduction and alkylation of proteins. A slight modification of the bulk dialysis method of Edelman and Poulik (8) was utilized for reduction and alkylation of the macroglobulin. Two to $10 \mathrm{ml}$ of a 1 to $3 \%$ solution of the protein in $0.05 \mathrm{M}$ phosphate, $7 \mathrm{M}$ urea (apparent $\mathrm{pH}$ 8), $0.1 \mathrm{M}$ mercaptoethanol, and $0.001 \mathrm{M}$ disodium ethylenediaminetetraäcetate were placed in a dialysis bag and surrounded by $100 \mathrm{ml}$ of the above solvent containing the mercaptan. After reaction at room temperature for 16 to 20 hours, a fivefold molar excess of iodoacetamide was added to the contents of the dialysis bag and the apparent $\mathrm{pH}$ adjusted to 8 with tris(hydroxymethyl)aminomethane. After 20 minutes the reaction mixture was dialyzed against changes of water for several days. The resulting product was insoluble in both water and saline. A sample of the purified Bence Jones protein was also treated in this manner.

To obtain soluble reduction products and to examine the antigenic character of the protein fractions, reduction and alkylation were performed in $0.2 \mathrm{M}$ phosphate at $\mathrm{pH}$ 8 in the absence of urea but with identical concentrations of the other reactants used in the above procedure (8). After alkylation, the protein was dialyzed against 0.1 $\mathrm{M} \mathrm{NaCl}$ solutions. When very small amounts of protein were available, the dialysis against the reducing agent was eliminated during reduction.

Dissociation and isolation of light chains of the macroglobulin. The reduced and alkylated $\gamma$-globulin proteins obtained by both methods of reduction mentioned above were dissociated by dialysis against $7 \mathrm{M}$ urea with $0.05 \mathrm{M}$ phosphate, apparent $\mathrm{pH} 6$ (8).

Separation of the $\mathrm{L}$ chains from the heavy polypeptide chains ( $\mathrm{H}$ chains) (3) was achieved by gel filtration in a manner modified but similar to that used in the separation of components of $\gamma_{2}$-globulin by Fleischman, Pain, and Porter (9). Columns containing Sephadex (G-100) equilibrated with $7 \mathrm{M}$ urea and $0.05 \mathrm{M}$ phosphate (apparent $\mathrm{pH}$ 6) were prepared immediately before use. Samples of the reduced and alkylated macroglobulins in the urea buffer were applied to the columns. Elution with the same buffer yielded two peaks on analysis by the Folin method. The second peak was dialyzed against $0.1 \mathrm{M} \mathrm{NaCl}$ buffered at $\mathrm{pH} 8$ and then against water and concentrated by lyophilization. Under similar conditions the reduction products of $7 \mathrm{~S} \gamma_{2}$-globulin, reduced and alkylated in buffers containing no urea, were isolated.

Starch gel electrophoresis. Vertical starch gel electrophoresis in urea at $\mathrm{pH} 3$ was performed in a manner essentially as described by Edelman and Poulik (8) with the modification that the concentration of urea in the gel was $7 \mathrm{M}$. Electrophoresis was conducted at $4^{\circ} \mathrm{C}$ for 16 to 20 hours at a gradient of 6 to $7 \mathrm{v}$ per $\mathrm{cm}$.

Peptide mapping of the proteins. One to $1 \frac{1}{2} \%$ suspensions of the lyophilized $\mathrm{L}$ chain of the macroglobulin or the Bence Jones protein previously reduced and alkylated in urea were reacted with trypsin in $0.02 \mathrm{M}$ ammonium acetate at $\mathrm{pH} 8.6$ for 18 hours at $37^{\circ}$. The trypsin to protein ratio was approximately 1 to 50 . A slight precipitate remaining in each of the samples was removed by centrifugation. The samples were then $1 \mathrm{y}$ ophilized to total dryness.

Solutions containing approximately 1.5 to $2.0 \mathrm{mg}$ of the trypsin digest were applied to Whatman $3 \mathrm{MM}$ paper $(46 \times 57 \mathrm{~cm})$ at one position. The peptides were separated by electrophoresis in an acetic acid-pyridine buffer (acetic acid 10: pyridine 1: water 189) at $\mathrm{pH} 3.6$ in the 


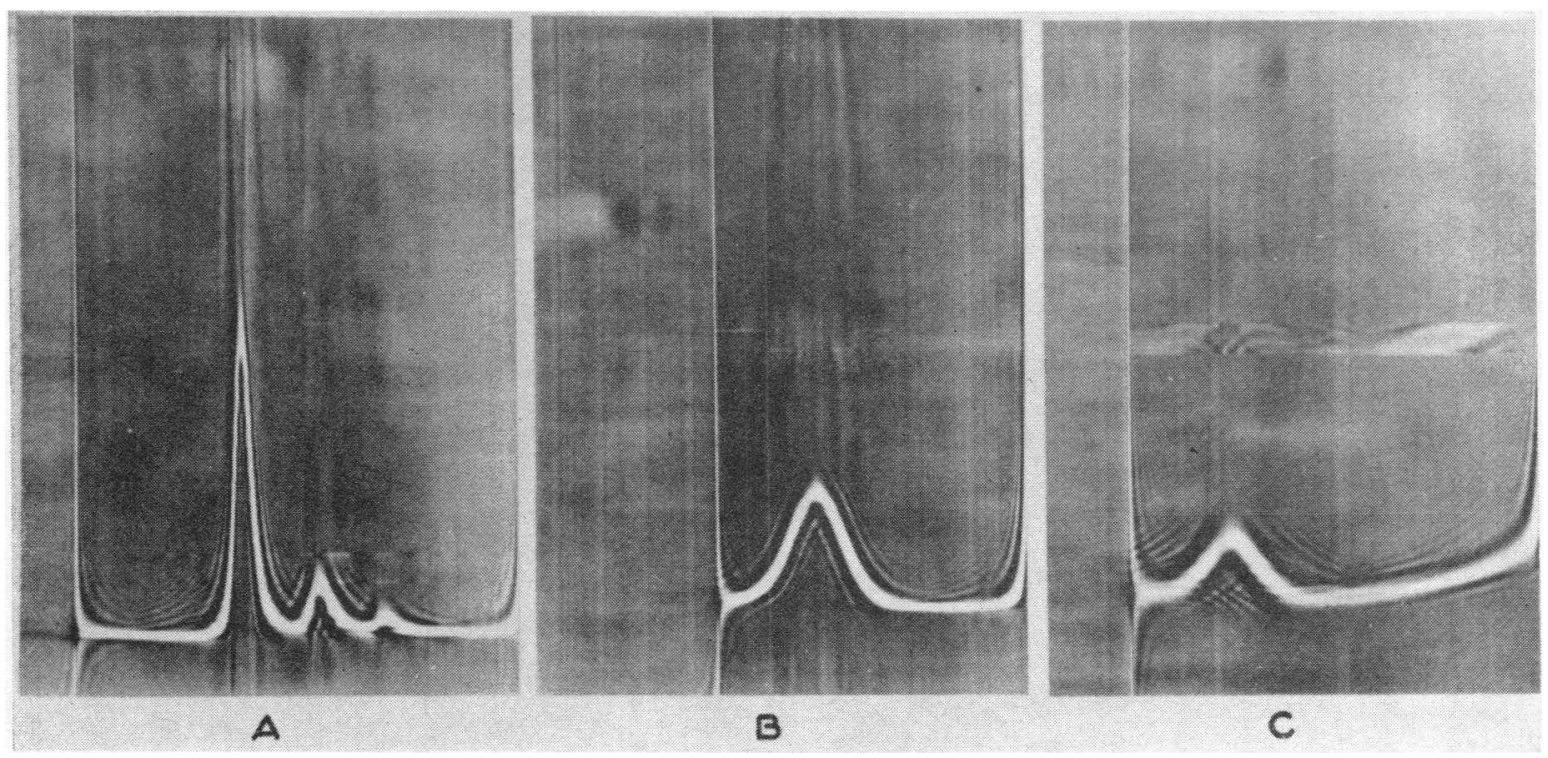

Fig. 1. Ultracentrifugal analysis of purified preparations. All pictures were taken at the indicated time after attaining full speed. Temperature: $20^{\circ} \mathrm{C}$. Solvent: $0.1 \mathrm{M} \mathrm{NaCl}$ and $0.01 \mathrm{M}$ phosphate at the indicated $\mathrm{pH}$.

A. Purified macroglobulin. $\mathrm{pH} 7$. Speed: $52,640 \mathrm{rpm}$. Time: 20 minutes. Angle: $60^{\circ}$. Concentration: $0.69 \%$.

B. Purified Bence Jones protein. $\mathrm{pH}$ 8. Speed: 59,780 rpm. Time: 48 minutes. Angle: $60^{\circ}$. Concentration: $0.90 \%$.

C. Light chain of macroglobulin. $\mathrm{pH}$ 7. Speed: 59,780 rpm. Time: 48 minutes. Angle: $45^{\circ}$. Concentration: $0.22 \%$.

apparatus described by Katz, Dreyer, and Anfinsen (10). Descending chromatography in the second dimension was performed using an $n$-butanol: acetic acid: water (120: $30: 50)$ solvent.

Peptides were detected by dipping the paper in $0.25 \%$ triketohydrindene hydrate (Ninhydrin) in acetone, heating the paper to 60 to $70^{\circ} \mathrm{C}$ for 15 minutes, and observing the development of the spots over a period of 48 hours. Photographs were taken after 48 hours of development.

Immunological techniques. Double-diffusion analysis was performed in agar buffered with a barbital buffer, $\mu=0.075, \mathrm{pH}$ 8.6. Immunoelectrophoresis was performed by standard techniques at this ionic strength and $\mathrm{pH}$. A horse antihuman serum, a specific horse antihuman $\gamma_{1}$-A $\left(\beta_{2 \Delta}\right), 6$ and a rabbit antiserum to human $\gamma$-globulin were used in this study.

\section{Results}

Characterization of the isolated macroglobulin. Ultracentrifugal examination of a $3.5 \%$ solution of the purified macroglobulin indicated no components with a sedimentation coefficient less than $17 \mathrm{~S}$. The macroglobulin showed three components (Figure 1A). The sedimentation coefficients $S_{20, w}$ for the two slowest components were

\footnotetext{
6 Hyland Laboratories, Los Angeles, Calif.
}

17.6 S and 25.8 S. The relative concentrations were 77 and $17 \%$, respectively. The remaining $6 \%$ of the protein had a sedimentation coefficient between 30 and $32 \mathrm{~S}$.

Isolation of urinary Bence Jones protein. The usual methods for isolation of Bence Jones protein by ammonium sulfate or euglobulin precipitation proved unsuitable in this case because of the relatively low concentration of protein (approximately $0.15 \%$ ) in the urine. Isolation of the nonalbumin urinary protein was accomplished by rapid adsorption of the dialyzed urine onto a $\mathrm{CM}$-cellulose column at $\mathrm{pH} 5$ with $0.01 \mathrm{M}$ acetate (Figure $2 \mathrm{a}$ ). About $40 \%$ of the protein (representing albumin) readily passed through the column and emerged in the first fraction. A gradient was applied to the column at point $\mathrm{A}$ in the figure. This gradient was formed by passing $0.025 \mathrm{M}$ phosphate, $\mathrm{pH} 7.4$, into a constant volume-mixing chamber containing $400 \mathrm{ml}$ of $0.01 \mathrm{M}$ acetate, $\mathrm{pH}$ 5.0. A second gradient, formed by passing 0.3 $\mathrm{M} \mathrm{NaCl}$ and $0.025 \mathrm{M}$ phosphate, $\mathrm{pH} 7.4$, into the contents of this mixing chamber, was applied at B. A final stepwise elution was performed with 0.5 $\mathrm{M} \mathrm{NaCl}$ at point $\mathrm{C}$. Just before application of the 


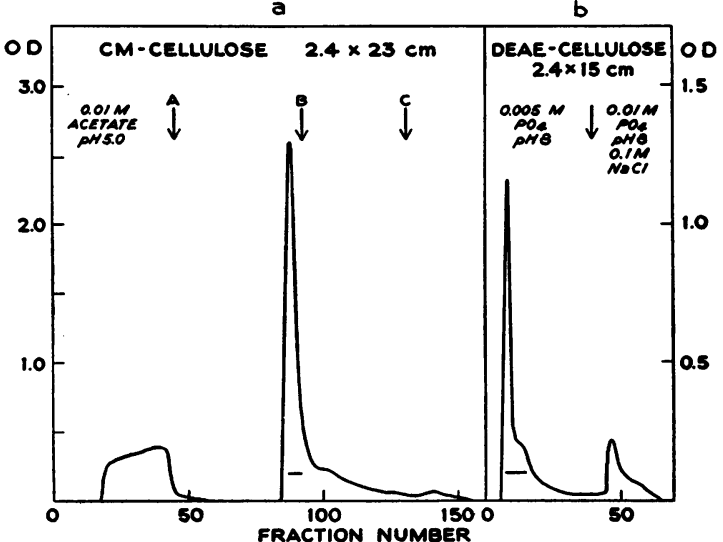

Fig. 2. Chromatographic isolation of the Bence Jones PRotein. The ordinate is OD at $280 \mathrm{~m} \mu$. a) Chromatography on CM-cellulose. $347 \mathrm{ml}$ of urine in $0.01 \mathrm{M}$ acetate, $\mathrm{pH} 5$, was passed through a CM-cellulose column. After removal of the first fraction, a gradient was applied at $\mathrm{A}$ and a second gradient at B. Stepwise elution with $0.5 \mathrm{M} \mathrm{NaCl}$ was started at $\mathrm{C}$. Fraction size: $11 \mathrm{ml}$. Protein recovery: $86 \%$. b) Chromatography on DEAE-cellulose. The fraction underlined in the second peak of " $\mathrm{a}$ " in $0.005 \mathrm{M}$ phosphate, $\mathrm{pH}$ 8.0, was passed through DEAE-cellulose equilibrated with the same buffer. The underlined initial fraction emerging from this column was used for the described work. Further material was eluted at higher ionic strength. Fraction size: $4 \mathrm{ml}$. Protein recovery : $75 \%$.

second gradient at $\mathrm{B}$, a large protein fraction emerged from the column. This fraction was concentrated and then equilibrated against 0.005 $\mathrm{M}$ phosphate at $\mathrm{pH} 8$. This material was placed upon a DEAE-cellulose column previously equilibrated with the same phosphate buffer (Figure $2 \mathrm{~b})$.

Stepwise elution with $0.005 \mathrm{M}$ phosphate, $\mathrm{pH} 8$, $0.1 \mathrm{M} \mathrm{NaCl}$, and $0.01 \mathrm{M}$ phosphate, $\mathrm{pH} 8$, yielded two fractions. The first fraction, which was used for all subsequent work, demonstrated the typical thermosolubility characteristics of Bence Jones protein.

This purified fraction consisted of a major and several very minor components as judged by starch gel electrophoresis in urea (Figure 4-5). Immunoelectrophoresis indicated a major and two minor components in the $\gamma$-globulin region, and with some antisera a trace of albumin could be detected.

Analytical ultracentrifugation of this purified Bence Jones protein revealed a single component with an $\mathrm{S}_{20, \mathrm{w}}$ value of $3.5 \mathrm{~S}$ (Figure $1 \mathrm{~B}$ ).
Isolation of the $L$ chains of the macroglobulin and $\gamma_{2}$-globulin. Reduction of the macroglobulin in urea solutions with mercaptoethanol and subsequent alkylation with iodoacetamide led to a product insoluble in dilute saline or water. Reduction and alkylation of the macroglobulin in buffer free of urea yielded a product soluble in salt solutions. This soluble product appeared as a single peak in the ultracentrifuge with an $\mathrm{S}_{20, \mathrm{w}}$ value of $6.0 \mathrm{~S}(10.7 \mathrm{mg}$ per $\mathrm{ml} ; 0.10 \mathrm{M} \mathrm{NaCl}$ and $0.01 \mathrm{M}$ phosphate, $\mathrm{pH} \mathrm{7)}$.

Gel filtration chromatography of each of these preparations on Sephadex G-100 in 7 M urea yielded a fraction that was excluded from the gel and one that entered the gel, the latter peaks being the $\mathrm{L}$ chains (Figure 3 ). As judged by the protein distribution, about $21 \%$ of the protein was in the second peak.

Separation of the two peaks in the case of the macroglobulin reduced in the absence of urea was virtually complete (Figure 3). However, separation of the components of the macroglobulin reduced in urea yielded some overlap of the two peaks. In these cases, rechromatography of the second peak under the same conditions was at times considered necessary.

The $\mathrm{L}$ chain of the macroglobulin reduced in the presence of urea was insoluble in saline and

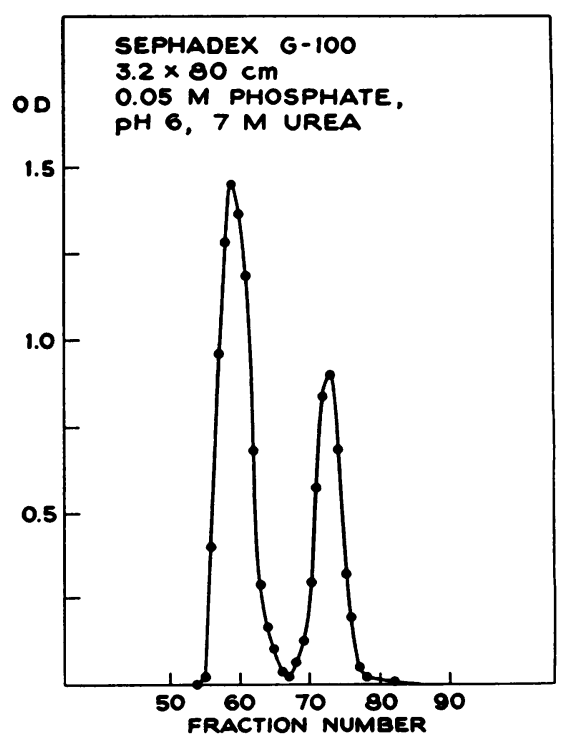

Fig. 3. Gel filtration of the maCroglobulin PREVIOUSLY REDUCED AND ALKYLATED IN A BUFFER CONTAINING No UREA. Applied sample: $4 \mathrm{ml}$. Fraction size: $4 \mathrm{ml}$. Ordinate: OD of Folin color at $750 \mathrm{~m} \mu$. Recovery : 87\%. 
water. The $\mathrm{L}$ chain of the macroglobulin reduced in the absence of urea was soluble in saline. This latter $L$ chain had an $S_{20, w}$ value of 3.6 $\mathrm{S}$ (Figure 1C).

The $\gamma_{2}$-globulins isolated from serum of the patient and from a normal serum failed to reveal the presence of $\gamma_{1 \Delta}$ or $\gamma_{1 M}$ globulins by immunoelectrophoresis. These proteins were subjected to reduction and alkylation in the absence of urea. Chromatography of these reduced proteins on Sephadex G-100 with the urea buffer yielded patterns similar to those obtained with the macroglobulins. The $\mathrm{L}$ chains of these $\gamma_{2}$-globulins were soluble in saline.

Electrophoresis in urea-starch gel. In Figure 4 is seen the pattern of the various protein preparations after electrophoresis in urea-starch gel at $\mathrm{pH}$ 3. Under these conditions the purified macroglobulin (Figure 4-1) showed a total inability to penetrate the starch gel and no indication of breaking into smaller and more mobile subunits.

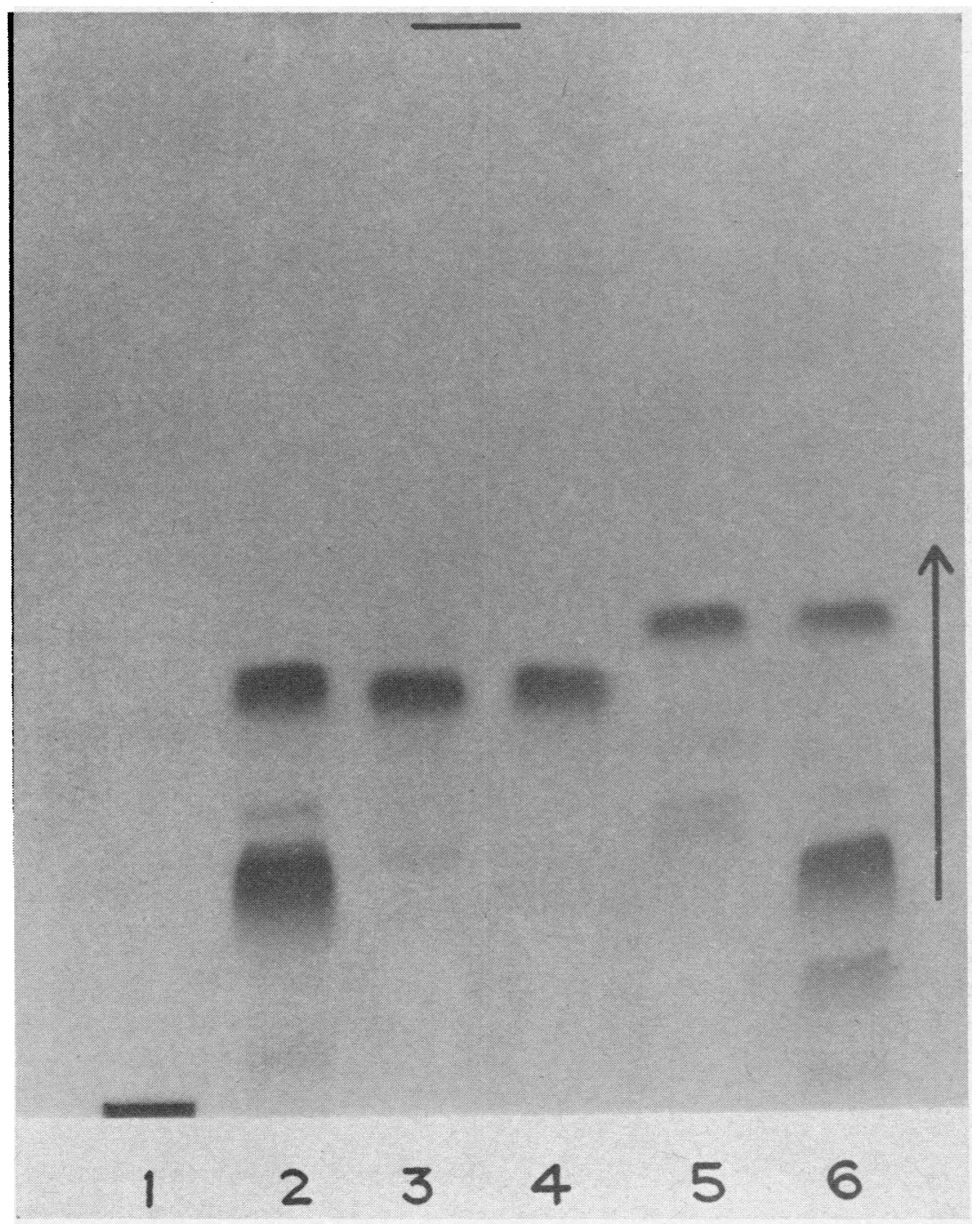

Fig. 4. ElECtrophoresis OF VARIOUS FRACTIONS IN UREA-STARCH GEL AT PH 3. The origin is at the bottom of the photograph, and the direction of migration is toward the cathode. 1) Purified macroglobulin, 2) macroglobulin reduced and alkylated in urea, 3) Bence Jones protein reduced and alkylated in urea, 4) L chain obtained from the macrogloblin reduced and alkylated in urea, 5) unmodified Bence Jones protein, and 6) macroglobulin reduced and alkylated in the absence of urea. The protein concentrations were 0.5 to $1.0 \%$. 

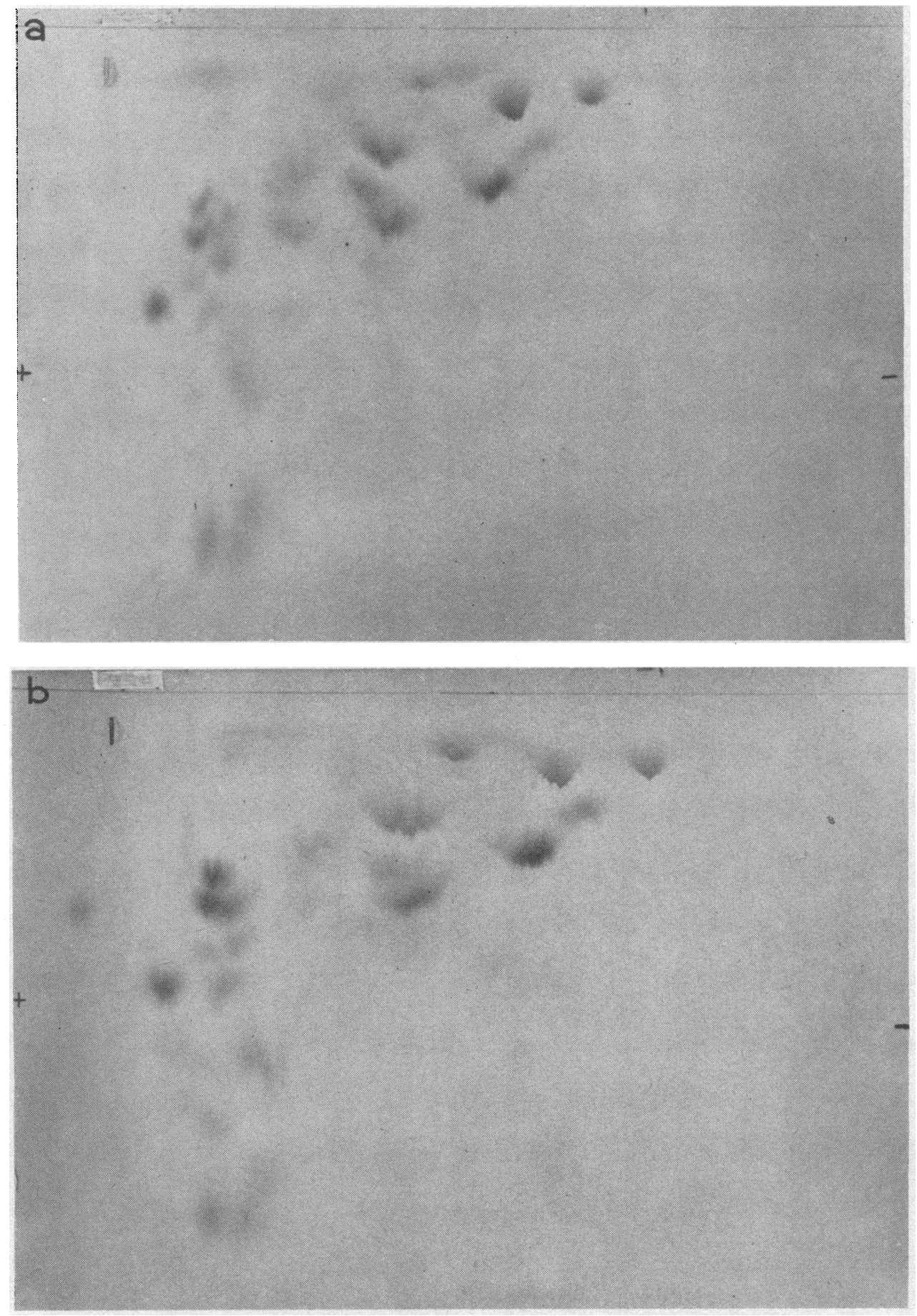

Fig. 5. PePtide maps derived from tryptic hydrolysis of Bence Jones PRotein and the isolated L CHAIN OF THE MACROGLOBUlin. Electrophoresis was at $1,000 \mathrm{v}(20 \mathrm{v}$ per cm) for $2 \frac{1}{2}$ hours. Descending chromatography was with an $n$-butanol, acetic acid, water solvent. Stain: Ninhydrin. Approximately $2 \mathrm{mg}$ of the digests was applied to the papers in the upper left-hand corner. a) Bence Jones protein; b) L chain of the macroglobulin. 
The macroglobulin reduced and alkylated in urea gave two well-stained bands (Figure 4-2), the more rapid band ( $\mathrm{L}$ chain) penetrating the gel about twice as far as the other band ( $\mathrm{H}$ chain). There were several less well-stained bands apparent.

The $\mathrm{L}$ chain isolated by gel filtration from the reduced macroglobulin (Figure 4-4) had the identical mobility of the more rapid component of this macroglobulin (Figure 4-2). This L chain preparation appeared to be free of the other components present in the reduced parent macroglobulin.

The Bence Jones protein reduced and alkylated in urea (Figure 4-3) showed the same mobility as the fast component of the macroglobulin or the isolated $\mathrm{L}$ chain of this macroglobulin reduced and alkylated under similar conditions (Figure 4-2, 4).

The macroglobulin reduced and alkylated in the absence of urea (Figure 4-6) also showed two strongly stained bands in addition to three faint bands. The more mobile component ( $\mathrm{L}$ chain) of this preparation penetrated further into the gel than did the corresponding $\mathrm{L}$ chain of the macroglobulin reduced in the presence of urea. The unreduced and unmodified Bence Jones protein (Figure 4-5) showed a rapid mobility in the gel and appeared to have the identical mobility of the $\mathrm{L}$ chain of the macroglobulin reduced and alkylated in the absence of urea.

Peptide mapping. Comparison of the Bence Jones protein with the $\mathrm{L}$ chain of the macroglobulin was performed by peptide mapping. Electrophoresis and chromatography of the trypsin hydrolysate of the Bence Jones protein and the $\mathrm{L}$ chain of the macroglobulin yielded apparently identical "fingerprints" (Figure 5a, b). The comparison was judged on the basis of relative position and relative color density of the Ninhydrin spots. There were few minor variations in color intensity between the two maps. No other stain was used.

Thermosolubility characteristics. Heating of the Bence Jones protein ( $4.7 \mathrm{mg}$ per $\mathrm{ml}$ ) and the soluble macroglobulin $\mathrm{L}$ chain ( $5 \mathrm{mg}$ per $\mathrm{ml}$ ) in an acetate buffer, $\mu=0.2, \mathrm{pH} 5$, produced distinct turbidity beginning at $56^{\circ} \mathrm{C}$. For the Bence Jones protein, decreased turbidity was noted at $90^{\circ}$ with greatly increased clearing at $100^{\circ}$. At this latter temperature a slight opalescence in the solu- tion was noted. For the $\mathrm{L}$ chain, clearing was noted near $80^{\circ}$ with a distinct clearing at $90^{\circ}$. A slight turbidity remained at $100^{\circ}$.

Immunodiffusion. Figure 6 shows the results of the diffusion of the Bence Jones protein and various soluble light chain preparations against a rabbit antiserum to human Fraction II. A line of complete identity appeared between the Bence Jones protein and the soluble light chain obtained from the macroglobulin, which is of antigenic Type I. ${ }^{7}$ The light chain of the patient's $\gamma_{2}$-globulin produced strong spur formation across the macroglobulin $\mathrm{L}$ chain and the Bence Jones protein. The precipitin line of the latter two proteins fused with the precipitin line of the $\gamma_{2}$-globulin $\mathrm{L}$ chain and showed no spur formation beyond the $\gamma_{2}$-globulin precipitin line. The $\mathrm{L}$ chain of the patient's $\gamma_{2}$-globulin formed a line of complete identity with the $\mathrm{L}$ chain of a $\gamma_{2}$-globulin obtained from a normal person. The faint precipitin band near the wells containing the $\mathrm{L}$ chain of the patient's $\gamma_{2}$-globulin is unexplained.

\section{Discussion}

The results of the present study are an extension of existing information on the structural relationships of Bence Jones proteins and serum myeloma proteins. Studies relating Bence Jones protein to the serum myeloma protein have been in terms of the $\mathrm{S}$ or slow fragment obtained by papain treatment (11-15) and the L polypeptide chain obtained by reduction and alkylation of the purified serum protein $(1,16,17)$. Antigenic differences between Bence Jones protein and the $S$ fragment of autologous myeloma protein have been demonstrated (18). By double diffusion methods, the $\mathrm{L}$ chain of myeloma protein does show a reaction of partial identity with the $S$ fragment of the same protein; however, the $\mathrm{L}$ chain more closely resembles the autologous Bence Jones protein than does the $\mathrm{S}$ fragment (19). Indeed, Edelman and Gally (1) have demonstrated that the $\mathrm{L}$ chain of a myeloma protein and the autologous Bence Jones protein after reduction and alkylation in the presence of urea had identical mobilities in urea-starch gel at $\mathrm{pH} 3$

\footnotetext{
${ }^{7}$ The antigenic type of the macroglobulin has been established by George M. Bernier, Department of Biochemistry, University of Florida.
} 
and showed similar amino acid compositions. The $\mathrm{L}$ chain prepared from this myeloma protein that had been reduced in the absence of urea was compared with the Bence Jones protein and showed similar thermosolubility characteristics. Similarly prepared $L$ chains of normal $\gamma_{2}$-globulin also show thermosolubility characteristics of Bence Jones proteins and thus demonstrate a fundamental similarity between an intrinsic structural component of $\gamma_{2}$-globulins and the urinary Bence Jones proteins (1).

Myeloma proteins and the autologous Bence Jones proteins usually have the same antigenic configuration in that they are either Type I or II (20) and $\operatorname{InV}(+)$ or $\operatorname{InV}(-)(21,22)$, suggesting a similarity of cellular or clonal origin.

Normal $\gamma_{2}$-globulin appears to be a mixture of the antigenic Types I and II (23), and recent evidence indicates that both these types also appear in macroglobulins obtained from normal serum (24), reflecting presumably the normal heterogeneity of cellular origin of both classes of $\gamma$-globulins.

Macroglobulinemia with Bence Jones proteinuria is distinctly less common than multiple myeloma and this proteinuria (25). The macroglobulins found in macroglobulinemia appear to

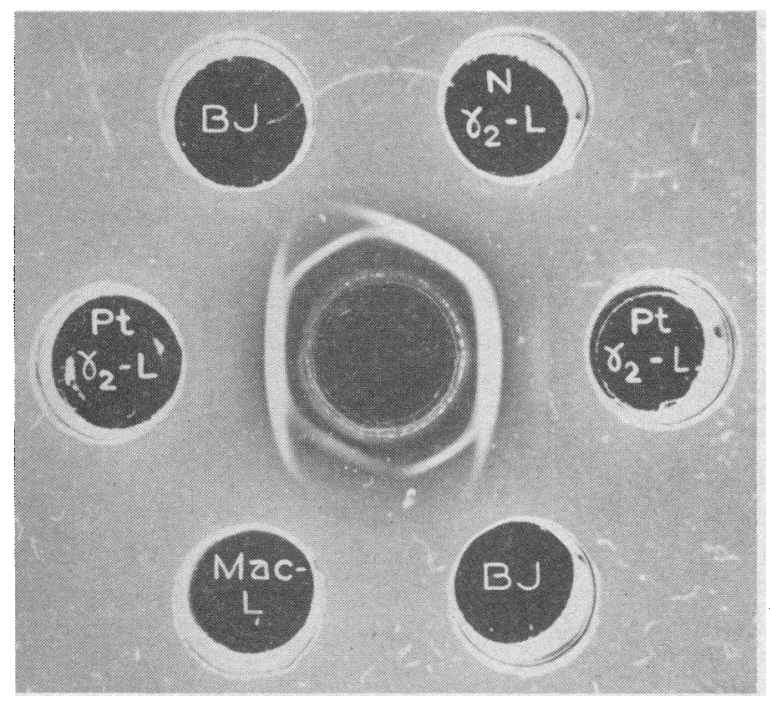

Fig. 6. ImMUNOdiffusion of the various SOlUble $L$ CHAIN PREPARATIONS FROM MACROGLOBULIN (MAC-L), PATIENT'S $\gamma_{2}$-GLOBULIN (PT- $\gamma_{2}-\mathrm{L}$ ), A NORMAL INDIVIDUAL'S $\gamma_{2}$-GLOBULIN (N- $\left.\gamma_{2}-\mathrm{L}\right)$, AND THE UNMODIFIED BENCE Jones PROTEIN (BJ). A rabbit antiserum to human $\gamma_{2}-$ globulin is in the center well. Diffusion was for 18 hours. carry only the antigenic determinants of Type I or II and to be $\operatorname{InV}(+)$ or $\operatorname{InV}(-)(20-22)$. We had anticipated that in a manner analogous to myeloma proteins and their autologous Bence Jones proteins, investigation of the present case would demonstrate a strong similarity, if not identity, of the $\mathrm{L}$ chain of the macroglobulin to the Bence Jones protein. We have isolated from the macroglobulin a polypeptide with a sedimentation value of $3.6 \mathrm{~S}$ and having thermosolubility characteristics of Bence Jones protein.

This peptide isolated from the macroglobulin, which had been reduced and alkylated in buffers containing no urea, and the unreduced and unmodified Bence Jones protein were compared by electrophoresis in urea-starch gels at $\mathrm{pH} 3$ and demonstrated identical mobilities. This result, taken with the fact that the peptide map of the Bence Jones protein and the isolated $\mathrm{L}$ chains are essentially identical, suggests that the $L$ chain of the macroglobulin obtained in the above manner is very similar, if not identical, in size, configuration, and charge to this Bence Jones protein. Schwartz and Edelman (26) have reported a comparable similarity in a comparison of the $\mathrm{L}$ polypeptide chains of myeloma globulin and autologous Bence Jones protein. Apparently the isolated $\mathrm{L}$ chain obtained from this macroglobulin after reduction and alkylation in buffers free of denaturing agents closely resembles native Bence Jones protein as it is excreted.

The $\mathrm{L}$ chain of the macroglobulin and the Bence Jones protein, when both had been reduced and alkylated in urea solutions, demonstrated in urea-starch gel a slower but identical mobility than their counterparts obtained without the use of urea. The slower mobilities of the proteins reduced in urea would be expected if intramolecular disulfide bonds were broken by the more drastic conditions of reduction leading to a more extensively unfolded molecule. Indeed, others have shown that ribonuclease, ovalbumin, human albumin, and the $\mathrm{L}$ and $\mathrm{H}$ chains of human $\gamma$-globulin extensively reduced and alkylated in $8 \mathrm{M}$ urea lead to molecules with slower mobility than the corresponding less reduced or unreduced proteins $(8,27)$.

In contrast to our results, Edelman and Gally (1) have given examples of unmodified Bence 
Jones protein migrating more slowly than the corresponding Bence Jones protein or $\mathrm{L}$ chain of the myeloma proteins reduced in the presence of urea.

The differences in mobility and solubility noted between the $\mathrm{L}$ chains of the macroglobulin prepared by reduction and alkylation in the absence or presence of urea undoubtedly reflect a difference in the extent of reduction of disulfide bonds in these polypeptides. Reduction of proteins by mercaptans in the presence of urea is more extensive than in the absence of urea (28). When pathologic macroglobulin was reduced with mercaptoethanol, many more disulfide bonds were broken with the macroglobulin reduced in the presence of urea than in the absence of urea (8). In all probability, the $\mathrm{L}$ chain obtained from the macroglobulin reduced in the presence of urea represents a far more extensively reduced product than the $\mathrm{L}$ chain produced by reduction of the macroglobulin that was not in the presence of urea.

In our own work, comparison of the $\mathrm{L}$ chains of the macroglobulin with the Bence Jones protein by double diffusion established the antigenic identity of the two proteins. In addition, the spur formation shown by the patient's own $\gamma_{2}$-globulin $\mathrm{L}$ chains with the Bence Jones protein and the $\mathrm{L}$ chain of the macroglobulin indicated the presence of determinants of both Types I and II in the patient's $\gamma_{2}$-globulin. The $\mathrm{L}$ chain of the $\gamma_{2}$-globulin did not have antigenic deficiencies when compared to the $\mathrm{L}$ chain of the $\gamma_{2}$-globulin obtained from a normal serum and by this criterion, therefore, appeared to be normal. Investigation of the normal population of macroglobulin molecules in this patient was not considered feasible.

The evidence presented here indicates that the patient's lymphoid cells are producing large amounts of unique macroglobulins belonging to antigenic Type I. In addition, this same cell line probably is producing the Bence Jones protein that is chemically and antigenically indistinguishable from the $\mathrm{L}$ chain of the macroglobulin.

Other cells of the lymphoid series are producing $\gamma_{2}$-globulin of Types I and II that are presumably normal. The findings are consistent with the concept that a certain population of lymphoid cells, probably arising from a single clone of cells, has extensively proliferated in this patient and is committed to the manufacture of a limited number of unique macroglobulin proteins belonging to one antigenic group.

This case represents a situation parallel to that in multiple myeloma, where much evidence has strongly suggested that both myeloma proteins and Bence Jones proteins are produced from a clone of cells that have extensively proliferated (29). Indeed, in this case of the transplantable mouse plasma-cell tumors' producing myeloma protein, the production of these proteins is directly related to the weight of the tumor (29). In addition, some of these mouse myeloma tumors also produce Bence Jones protein. Askonas and Fahey (30) have shown that the Bence Jones protein was neither a precursor nor a breakdown product of the myeloma protein in one of these mouse tumors. Putnam and Hardy (31) have found that Bence Jones proteins were not breakdown products of the myeloma protein. The data are consistent with the view that Bence Jones proteins are manufactured at a rate independent of the myeloma proteins. Edelman and Benacerraf (3) have postulated that the uncontrolled asynchronous synthesis of the $\mathrm{L}$ chain of myeloma protein is responsible for the appearance of Bence Jones protein in the urine.

An over-all similarity between macroglobulinemia with Bence Jones proteinuria and myeloma and its corresponding proteinuria (26) appears to exist. There has been no definitive evidence to date that the distinctive $7 \mathrm{~S}$ or $19 \mathrm{~S}$ proteins of these diseases are abnormal. Rather it is distinctly possible that these several serum proteins and Bence Jones proteins are expressions of some regulatory dysfunction of an otherwise normal population of lymphoid cells. The Bence Jones proteinuria of macroglobulinemia is far rarer than the proteinuria of myeloma (25). Whether this fact represents a difference in the mechanism leading to increased synthesis of $\mathrm{L}$ chains or decreased synthesis of $\mathrm{H}$ chains is not known. With the establishment of additional qualitative similarities between normal serum and urinary proteins and the proteins associated with these two diseases, future studies should be directed toward the basic mechanisms regulating the rate of synthesis of $\gamma$-globulins and Bence Jones proteins. 


\section{Summary}

A comparison was made between the serum and urine proteins isolated from a patient with Waldenström's macroglobulinemia and Bence Jones proteinuria. After reduction and alkylation in a solvent containing no denaturing agent, the macroglobulin was separated into $\mathrm{H}$ and $\mathrm{L}$ chains by gel filtration on urea-Sephadex G-100. The L chain of the macroglobulin and the Bence Jones protein had similar thermosolubility characteristics and sedimentation values on analytic ultracentrifugation.

On electrophoresis in urea-starch gel, the unmodified Bence Jones protein had the identical mobility of the $\mathrm{L}$ chain of the macroglobulin. $\mathrm{L}$ chains and Bence Jones protein prepared by reduction in urea buffers had identical but slower mobilities than the proteins reduced in buffers without urea. Peptide maps of these proteins appeared to be identical.

The $\mathrm{L}$ polypeptide chain of the serum macroglobulin and the urinary Bence Jones protein were both of Type I, whereas the L chain of the autologous serum $\gamma_{2}$-globulin manifested both Types I and II antigenic specificity.

This study strongly suggests the chemical and immunologic identity of a Bence Jones protein and the $\mathrm{L}$ chain of the autologous serum macroglobulin.

\section{Acknowledgment}

The able assistance of Mr. William R. Kane is gratefully acknowledged.

\section{References}

1. Edelman, G. M., and J. A. Gally. The nature of Bence-Jones proteins. Chemical similarities to polypeptide chains of myeloma globulins and normal $\gamma$-globulins. J. exp. Med. 1962, 116, 207.

2. Putnam, F. Structural relationships among normal human $\boldsymbol{\gamma}$-globulin, myeloma globulins, and BenceJones proteins. Biochim. biophys. Acta. (Amst.) 1962, 63, 539.

3. Edelman, G. M., and B. Benacerraf. On structural and functional relations between antibodies and proteins of the gamma-system. Proc. nat. Acad. Sci. (Wash.) 1962, 48, 1035.

4. Lowry, O. H., N. J. Rosebrough, A. L. Farr, and R. J. Randall. Protein measurement with the Folin phenol reagent. J. biol. Chem. 1951, 193, 265.

5. Schachman, H. K. Ultracentrifugation, diffusion and viscometry in Methods in Enzymology, S. P. Colo- wick and N. A. Kaplan, Eds. New York, Academic Press, 1957, vol. 4, p. 32.

6. Epstein, W. V., and H. Fudenberg. Demonstration of Gm 1(a) and anti-Gm 1(a) specificities by tanned cells coated with individual $\gamma$-globulins. J. Immunol. 1962, 89, 293.

7. Putnam, F. W., C. W. Easley, L. T. Lynn, A. E. Ritchie, and R. A. Phelps. The heat precipitation of Bence-Jones proteins. I. Optimum conditions. Arch. Biochem. 1959, 83, 115.

8. Edelman, G. M., and M. D. Poulik. Studies on the structural units of the $\gamma$-globulins. J. exp. Med. $1961,113,861$.

9. Fleischman, J. B., R. H. Pain, and R. R. Porter. Reduction of $\gamma$-globulins. Arch. Biochem. 1962, 98, suppl. 1, 174.

10. Katz, A. M., W. J. Dreyer, and C. B. Anfinsen. Peptide separation by two-dimensional chromatography and electrophoresis. J. biol. Chem. 1959, 234, 2897.

11. Franklin, E. C., and D. R. Stanworth. Antigenic relationships between immune globulins and certain related paraproteins in man. J. exp. Med. 1961, 114, 521.

12. Olins, E. E., and G. M. Edelman. The antigenic structure of the polypeptide chains of human $\gamma$-globulin. J. exp. Med. 1962, 116, 635.

13. Putnam, F. W., S. Migita, and C. W. Easley. Structural and immunochemical relationships among Bence-Jones proteins in Protides of the Biological Fluids, 10th Colloquium, H. Peeters, Ed. Amsterdam, Elsevier Publishing Co., 1962, p. 93.

14. Migita, S., and F. W. Putnam. Antigenic relationships of Bence-Jones proteins, myeloma globulins and normal human gamma globulin. J. exp. Med. 1963, 117, 81.

15. Askonas, B. A., and J. L. Fahey. Enzymatically produced subunits of proteins formed by plasma cells in mice. II. $\beta_{2 \mathrm{~A}}$-Myeloma protein and Bence-Jones protein. J. exp. Med. 1962, 115, 641.

16. Poulik, M. D., and G. M. Edelman. Comparison of reduced alkylated derivatives of some myeloma globulins and Bence-Jones proteins. Nature (Lond.) 1961, 191, 1274.

17. Edelman, G. M. Structural relations between normal and pathologic $\gamma$-globulins. Ann. N. Y. Acad. Sci. 1962, 101, 246.

18. Stiehm, E. R., J. I. Morton, and H. F. Deutsch. Some immunologic properties of papain digest fragments of multiple myeloma proteins. J. Immunol. 1960, 85, 337.

19. Olins, D. E., and G. M. Edelman. The antigenic structure of the polypeptide chains of human $\gamma$-globulin. J. exp. Med. 1962, 116, 635.

20. Mannik, M., and H. G. Kunkel. Classification of myeloma proteins, Bence-Jones proteins, and macroglobulins into two groups on the basis of common antigenic characters. J. exp. Med. 1962, 116, 859. 
21. Franklin, E. C., H. Fudenberg, M. Meltzer, and D. R. Stanworth. The structural basis for genetic variations of normal human $\boldsymbol{\gamma}$-globulins. Proc. nat. Acad. Sci. (Wash.) 1962, 48, 914.

22. Harboe, M., C. K. Osterland, and H. G. Kunkel. Localization of two genetic factors to different areas of $\gamma$-globulin molecules. Science 1962, 136, 979.

23. Mannik, M., and H. G. Kunkel. Two major types of normal 7 S $\gamma$-globulin. J. exp. Med. 1963, 117, 213.

24. Fahey, J. L. Heterogeneity of gamma globulins in Advances in Immunology, W. H. Taliaferro and J. H. Humphrey, Eds. New York, Academic Press, 1962, vol. 2, p. 41.

25. Baars, H., J. W. Imhof, and J. de Wael. Serum and urinary proteins in macroglobulinemia of Waldenström. An investigation of 7 cases treated by the authors and a review of 107 cases from the literature in Protides of the Biological Fluids, 6th Colloquium, H. Peeters, Ed. Amsterdam, Elsevier Publishing Co., 1959, p. 131.

26. Schwartz, J. H., and G. M. Edelman. Comparisons of Bence-Jones proteins and $\mathrm{L}$ polypeptide chains of myeloma globulins after hydrolysis with trypsin. J. exp. Med. 1963, 118, 41.

27. Poulik, M. D., and G. M. Edelman. Application of starch gel electrophoresis in urea to the study of structural units of proteins in Protides of the Biological Fluids, 9th Colloquium, H. Peeters, Ed. Amsterdam, Elsevier Publishing Co., 1962, p. 126.

28. Thompson, E. O. P. The selective degradation of proteins in Advances in Organic Chemistry, R. A. Raphael, E. C. Taylor, and H. Wynberg, Eds. New York, Interscience Publishers, 1960, vol. 1, p. 149.

29. Fahey, J. L. Evidence for heterogeneity of plasma cells : studies of proteins produced by plasma cell tumors in inbred mice. Ann. N. Y. Acad. Sci. 1962, 101, 221.

30. Askonas, B. A., and J. L. Fahey. Formation of Bence-Jones protein and myeloma protein in vitro by the plasma-cell tumour MPC-2. Biochem. J. 1961, 80, 261.

31. Putnam, F. W., and S. Hardy. Proteins in multiple myeloma. III. Origin of Bence-Jones protein. J. biol. Chem. 1955, 212, 361. 